\title{
Enhancing the Efficiency of Solar Panel Using Cooling Systems
}

\author{
Nair Milind*, Midhun Antony*, Febin Francis*, Jithu Francis*, \\ Joson Varghese*, Sajith U K** \\ *(UG Scholar, Department of Mechanical Engineering, Jyothi Engineering College, Thrissur, India) \\ ** (Assistant Professor, Department of Mechanical Engineering, Jyothi Engineering College, Thrissur, India)
}

\begin{abstract}
The recent upsurge in the demand of photovoltaic systems is due to the fact that they produce electric power without causing much damage to the environment by directly converting the solar radiation into electric power. Solar energy is completely natural, it is considered as a clean energy source. So the study on enhancing the efficiency of solar panel is very necessary. Photovoltaic cells get overheated due to excessive solar radiation and ambient temperature. Therefore to rectify this problem different cooling systems are used so as to maintain the temperature of the cells
\end{abstract}

Keywords: Cooling system, Efficiency, Photovoltaic cell, Solar energy, Temperature

\section{INTRODUCTION}

Currently the world is facing the problem of energy deficit, global warming, and deterioration of environment and energy sources; there is a need for an alternative energy resource for power generation other than use of fossil fuels, water and wind. Fossil fuel will get depleted in next few decades, hydro power plants depend on annual rainfall and wind power depends on climate changes. Like water and air, the sun is one of earth's life support system providing heat and light. Solar energy which is renewable widely available and clean provides enough energy to meet the worlds annual consumption needs. The power from the sun intercepted by the earth is approximately $1.8 \times 10^{11} \mathrm{MW}$ which is larger than the present consumption rate on the earth of all commercial energy sources. Thus solar energy could supply all the present and future energy needs of the world on a continuing basis. This makes it one of the most promising of the unconventional energy sources.

One of the major technologies used for harnessing the solar energy is photovoltaic solar technology. In photovoltaic solar technology a panel consisting of many solar cells is used. A solar cell is a semiconductor device that directly converts the energy from sunlight into electrical energy through the process of photovoltaic. The photovoltaic cell (solar cell) converts only a small fraction ( less than $20 \%)$ of the irradiance into electrical energy the valances' converted into heating of the cell. One of the important parameters that affect the energy output of the PV module or the system is the operating temperature. The electrical efficiency of the cells decreases with temperature increase. Cooling can improve the electrical production of standard flat panel PV modules, since cooling keeps the PV cells from reaching temperature at which irreversible damage occurs. It has been found that the efficiency and output power of PV module is inversely proportional to its temperature.

\section{PROBLEM STATEMENT}

Excessive heat significantly reduces the overall efficiency of the solar panel. As the temperature increases the voltage output decreases linearly. Hence to counter this problem cooling system is placed so as to eliminate excessive heating of the panel.

\section{OBJECTIVE AND SCOPE}

The goal of this project is to enhance the efficiency of solar panel using an apt cooling system. The scope if this project is that it will help in lowering the degradation of panel and higher longevity for the panel.

\section{METHODOLOGY}

A commercial polycrystalline solar panel is used of area $60 \mathrm{~cm} \times 60 \mathrm{~cm}$. The load is connected to the panel .The readings of voltage and current are taken with the help of digital multimeter every 15 minutes starting from 11:00 am to 2:00 pm (peak time of solar irradiance) for five days and average is taken. The temperature of panel is measured using thermocouple (K-type) at five different places and average is taken. From the observations it is seen that there is constant drop in voltage with increase in temperature which results in drop in power generated. 


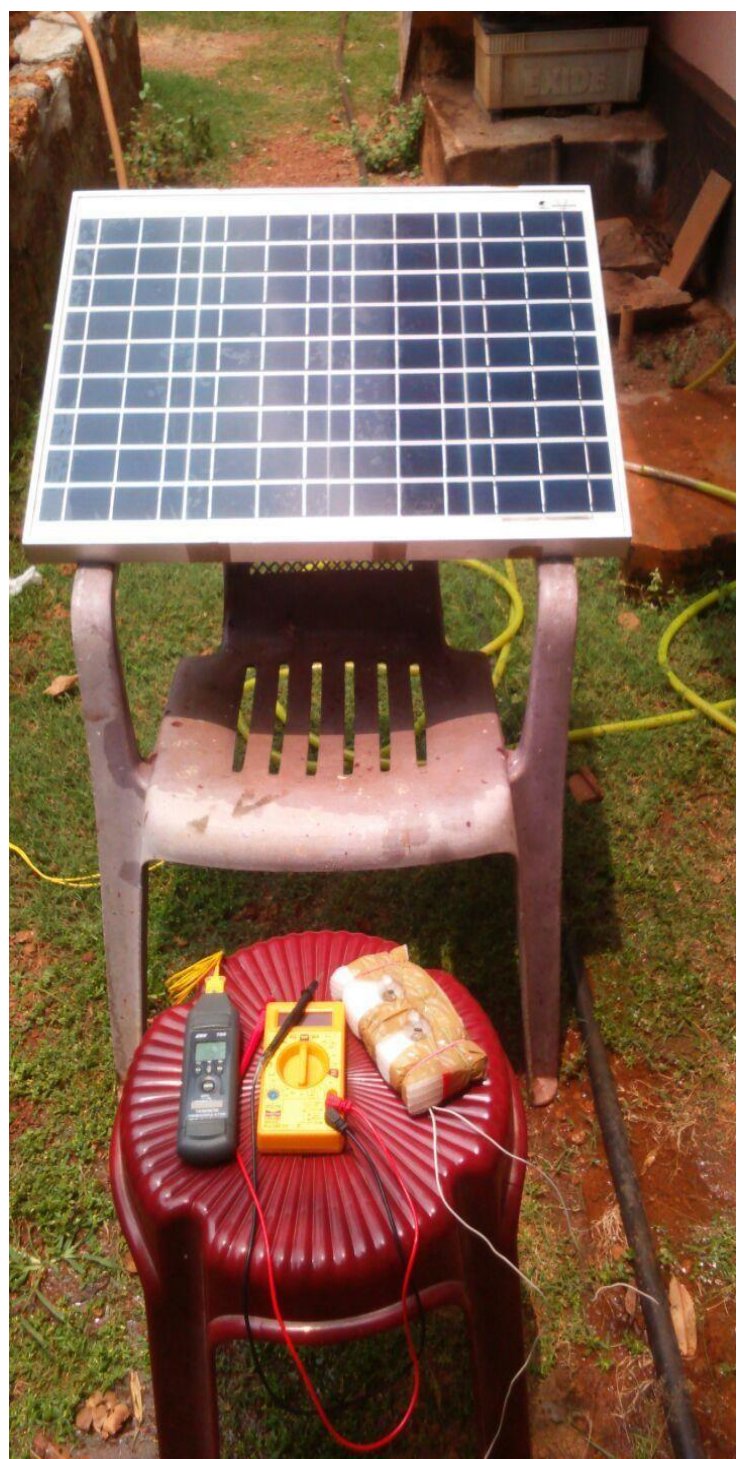

Figure 1 Initial setup of experiment

\begin{tabular}{|l|l|l|l|l|l|}
\hline Si. No. & Time & $\begin{array}{l}\text { Temperature } \\
\left({ }^{(} \mathrm{C}\right)\end{array}$ & $\begin{array}{l}\text { Voltage } \\
\text { (V) }\end{array}$ & $\begin{array}{l}\text { Current } \\
(\mathrm{A})\end{array}$ & $\begin{array}{l}\text { Porrer } \\
\text { (V) }\end{array}$ \\
\hline 1 & $11: 00 \mathrm{am}$ & 32 & 17.5 & 1.51 & 25.9 \\
\hline 2 & $11: 15 \mathrm{am}$ & 50.2 & 17.2 & 1.47 & 25.38 \\
\hline 3 & $11: 30 \mathrm{am}$ & 52.4 & 17.26 & 1.44 & 24.38 \\
\hline 4 & $11: 45 \mathrm{am}$ & 60 & 17.2 & 1.44 & 24.61 \\
\hline 5 & $12: 00 \mathrm{pm}$ & 62.3 & 16.92 & 1.43 & 24.36 \\
\hline 6 & $12: 15 \mathrm{pm}$ & 63 & 16.87 & 1.43 & 24.12 \\
\hline 7 & $12: 30 \mathrm{pm}$ & 64.1 & 16.7 & 1.43 & 23.88 \\
\hline 8 & $12: 45 \mathrm{pm}$ & 65.63 & 16.72 & 1.42 & 23.745 \\
\hline 9 & $1: 00 \mathrm{pm}$ & 64.78 & 16.62 & 1.42 & 23.61 \\
\hline 10 & $1: 15 \mathrm{pm}$ & 64.79 & 16.23 & 1.45 & 23.54 \\
\hline 11 & $1: 30 \mathrm{pm}$ & 64.7 & 16.41 & 1.43 & 23.47 \\
\hline 12 & $1: 45 \mathrm{pm}$ & 64 & 16.45 & 1.43 & 23.53 \\
\hline 13 & $2: 00 \mathrm{pm}$ & 63.5 & 16.39 & 1.42 & 23.53 \\
\hline
\end{tabular}

Table 1 Without any cooling system

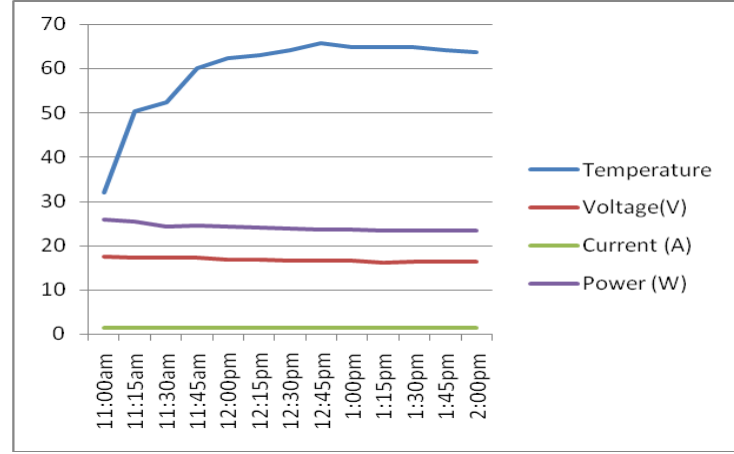

Graph 1 without any cooling system

\section{FREE FLOW FRONT WATER COOLING SYSTEM}

In free front flow water cooling, the water is made to flow over the surface of the panel. The cooling system consist of a $3 / 4$ inch polyvinylchloride (PVC) pipe of length 27 inches, ball valve of $3 / 4$ inch, hose nipple for connecting the garden hose to the ball valve, for collecting water a 4-inch pipe of length $27 \mathrm{inch}$ and its stopper is used. The flow of the water is controlled using the ball valve. Holes were drilled in the $3 / 4$ inch pipe so as to accommodate the flow of water uniformly over the surface of the panel. The readings of voltage and current where taken, during the same time period (11:00am to 2:00pm) for five days and average of those readings were taken.

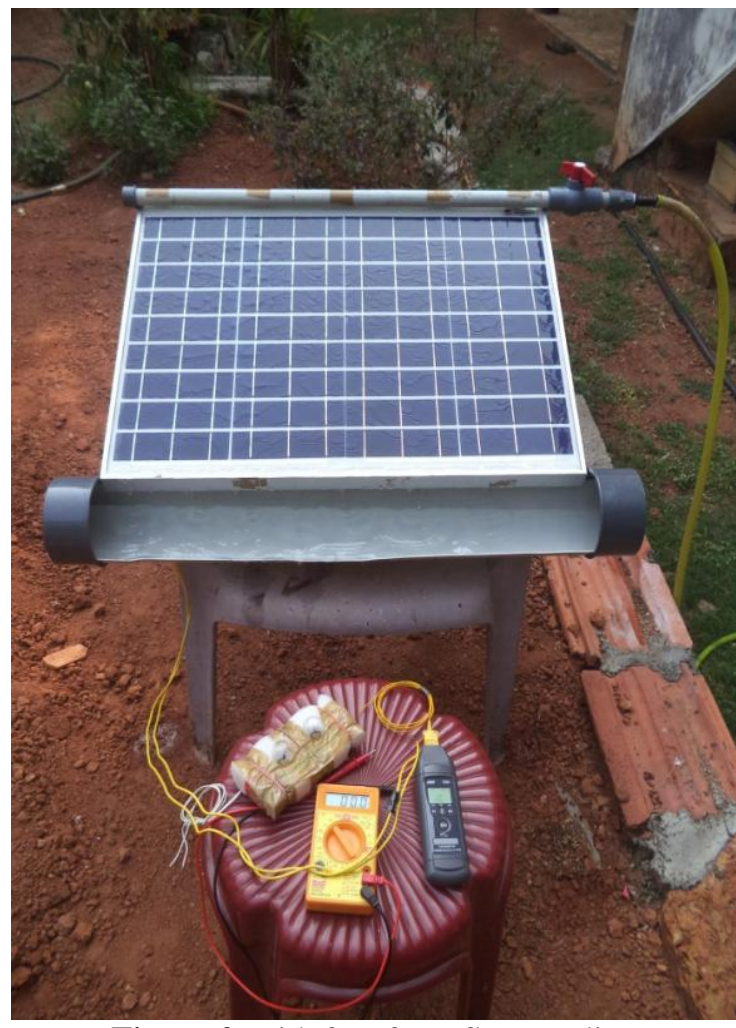

Figure 2 With free front flow cooling 


\begin{tabular}{|l|l|l|l|l|}
\hline $\begin{array}{l}\text { Si. } \\
\text { No. }\end{array}$ & Time & $\begin{array}{l}\text { Power (W) With free } \\
\text { front flow cooling }\end{array}$ & $\begin{array}{l}\text { Power (W) Without } \\
\text { cooling }\end{array}$ & $\begin{array}{l}\text { Percentage increase } \\
\text { in Power (W) }\end{array}$ \\
\hline 1 & $11: 00 \mathrm{am}$ & 27.21 & 25.9 & 5.05 \\
\hline 2 & $11: 15 \mathrm{am}$ & 27.40 & 25.38 & 7.97 \\
\hline 3 & $11: 30 \mathrm{am}$ & 27.6 & 24.38 & 11.02 \\
\hline 4 & $11: 45 \mathrm{am}$ & 27.87 & 24.61 & 13.26 \\
\hline 5 & $12: 00 \mathrm{pm}$ & 28.15 & 24.36 & 15.55 \\
\hline 6 & $12: 15 \mathrm{pm}$ & 28.295 & 24.12 & 17.30 \\
\hline 7 & $12: 30 \mathrm{pm}$ & 28.44 & 23.88 & 19.05 \\
\hline 8 & $12: 45 \mathrm{pm}$ & 27.74 & 23.745 & 16.85 \\
\hline 9 & $1: 00 \mathrm{pm}$ & 27.04 & 23.61 & 14.52 \\
\hline 10 & $1: 15 \mathrm{pm}$ & 27 & 23.54 & 14.69 \\
\hline 11 & $1: 30 \mathrm{pm}$ & 26.96 & 23.47 & 14.87 \\
\hline 12 & $1: 45 \mathrm{pm}$ & 27.35 & 23.53 & 16.25 \\
\hline 13 & $2: 00 \mathrm{pm}$ & 27.75 & 23.59 & 17.63 \\
\hline
\end{tabular}

Table 2 With free front flow cooling

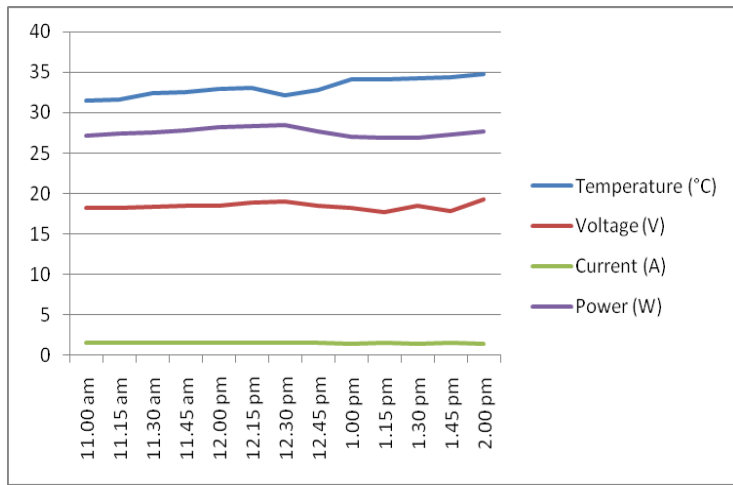

Graph 2 With free front flow cooling

A comparison between the two shows that there is an average increse in power of about $14.15 \%$.

\begin{tabular}{|l|l|l|l|l|}
\hline $\begin{array}{l}\text { Si. } \\
\text { No. }\end{array}$ & Time & $\begin{array}{l}\text { Power (W) With free } \\
\text { front flow cooling }\end{array}$ & $\begin{array}{l}\text { Power (W) Without } \\
\text { cooling }\end{array}$ & $\begin{array}{l}\text { Percentage increase } \\
\text { in Power (W) }\end{array}$ \\
\hline 1 & $11: 00 \mathrm{am}$ & 27.21 & 25.9 & 5.05 \\
\hline 2 & $11: 15 \mathrm{am}$ & 27.40 & 25.38 & 7.97 \\
\hline 3 & $11: 30 \mathrm{am}$ & 27.6 & 24.38 & 11.02 \\
\hline 4 & $11: 45 \mathrm{am}$ & 27.87 & 24.61 & 13.26 \\
\hline 5 & $12: 00 \mathrm{pm}$ & 28.15 & 24.36 & 15.55 \\
\hline 6 & $12: 15 \mathrm{pm}$ & 28.295 & 24.12 & 17.30 \\
\hline 7 & $12: 30 \mathrm{pm}$ & 28.44 & 23.88 & 19.05 \\
\hline 8 & $12: 45 \mathrm{pm}$ & 27.74 & 23.745 & 16.85 \\
\hline 9 & $1: 00 \mathrm{pm}$ & 27.04 & 23.61 & 14.52 \\
\hline 10 & $1: 15 \mathrm{pm}$ & 27 & 23.54 & 14.69 \\
\hline 11 & $1: 30 \mathrm{pm}$ & 26.96 & 23.47 & 14.87 \\
\hline 12 & $1: 45 \mathrm{pm}$ & 27.35 & 23.53 & 16.25 \\
\hline 13 & $2: 00 \mathrm{pm}$ & 27.75 & 23.59 & 17.63 \\
\hline
\end{tabular}

Table 3 Percentage increase in power

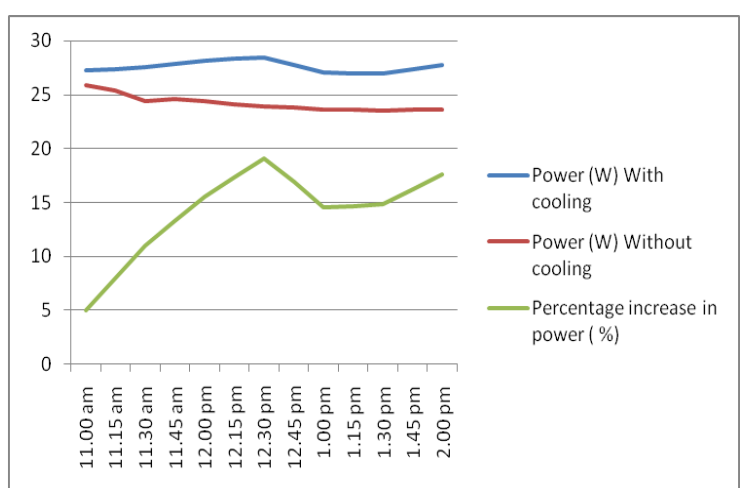

Graph 3 Percentage increase in power

\section{CONCLUSION}

Free flow front water cooling of PV panels can improve the efficiency and reliability of photovoltaic energy conversion - the open voltage of the panels is increasing when its temperature decreasing and due to the lower operating temperature, its life cycle could be increase.

\section{ACKNOWLEDGEMENT}

The authors would like to thank Department of mechanical Engineering, Jyothi Engineering College, Cheruthuruthy, Kerala, for their technical support and valuable suggestions.

\section{REFERENCES}

[1]. Mrs. Rupali Nazar review on"Improvement of efficiency of solar panel using different", International Journal of Electrical and Electronics Engineers, ISSN-2321-2055 (E)IJEEE, Volume 07,Issue 01, JanuaryJune 2015

[2]. Mr. Sayaran A. Abdulgafer et al. review article on "Improving the efficiency of polycrystalline solar panel by water emersion method" International Journal for innovative research in science, ISSN 2319-8753, Volume 3, Issue 01, January 2014

[3]. Mr. B.Balamuralikrishnan et al. review article on "Efficiency enhancement of photovoltaic cell" International Journal of Electrical Electronics Instrumentation Engineering ISSN 2320-3765, Volume 03, Issue 04, May-2014

[4]. Mr. Saurabh Mehrotra et al. review article on "Performance of a solar panel with water immersion cooling technique" International Journal of Science, Environment ISSN 2278-3687 (O), Volume 3, No 3, 2014, $1161-1172$ 